\title{
Using Padlet for Collaborative Writing among ESL Learners
}

\author{
Aida Abdul Rashid', Melor Md Yunus², Wahiza Wahi' \\ ${ }^{1}$ Pusat Citra, Universiti Kebangsaan Malaysia, Bandar Baru Bangi, Malaysia \\ ${ }^{2}$ Faculty of Education, Universiti Kebangsaan Malaysia, Bandar Baru Bangi, Malaysia \\ Email: aidarashid@ukm.edu.my, melor@ukm.edu.my,Wawa@ukm.edu.my
}

How to cite this paper: Rashid, A. A., Yunus, M. M., \& Wahi, W. (2019). Using Padlet for Collaborative Writing among ESL Learners. Creative Education, 10, 610-620.

https://doi.org/10.4236/ce.2019.103044

Received: January 8, 2019

Accepted: March 26, 2019

Published: March 29, 2019

Copyright $\odot 2019$ by author(s) and Scientific Research Publishing Inc. This work is licensed under the Creative Commons Attribution International License (CC BY 4.0).

http://creativecommons.org/licenses/by/4.0/

\section{c) (i) Open Access}

\begin{abstract}
The lack of language skills among ESL learners could affect their ability to work collaboratively at the undergraduate level. This study looks at how collaborative writing in a language course could be enhanced by the use of an interactive on-line tool called Padlet. 87 participants taking a language course in a public university in Malaysia were involved in the research. The study was aimed to improve language and communication skills, increase motivation, lower anxiety and encourage students to become more autonomous. A series of tasks were designed using Padlet and carried out through the semester. Student's posts and feedback in the form of a questionnaire were analysed. The findings showed that Padlet motivates students to participate in class activities, lower anxiety, encourages interaction among class members and instructor, and improves language accuracy through learning from peers. Padlet could be effectively used in an undergraduate course to facilitate collaborative writing among lower proficiency ESL learners.
\end{abstract}

\section{Keywords}

Collaborative Learning and Writing, Padlet, Academic Writing, Lower Proficiency, ESL Learners

\section{Introduction}

The process of teaching and learning in today's higher education involves mobile and online applications, which has enhanced communication among students and teachers and enabling learning to go beyond the walls of the classroom. Incorporating these elements in the class results in increased motivation, more fun and effective learning. There is a plethora of applications and web tools used by educators around the world such as Facebook, Edmodo, MOOC, 
Blogs, Youtube, Google classroom, Telegram, just to name a few.

There has been a substantial research in how collaboration could enhance the learning process. Wells (2000) showed that new knowledge is built upon current knowledge as learners communicate in order to accomplish their objectives together. Wenger (1998) stated that individual learners would have the support of the social group as they interact and learn from each other. According to Swain (2000), collaborative dialogue constructs linguistic knowledge where learners are presented with the opportunity to use the language and reflect on their own language use. The element of peer involvement has shown increase in motivation and enjoyment in achieving a task in a group.

Collaborative writing is an essential part of the academic world. There have been many advantages to collaborative writing in the aspect of language learning among ESL or L2 learners. Storch (2005) found that it produces better text fulfillment and grammatical accuracy and complexity. Shehadeh (2011) showed how it contributed to L2 learners in terms of content, organization and vocabulary. Lin and Maarof (2013) found that collaborative writing enhanced learner's writing and language proficiency. Most of these research highlighted classroom based tasks, where activities are carried out in class and closely monitored by the instructor. This study however employs an on-line tool to enable collaborative tasks to be done out of the classroom by students and their group members on their own. The effectiveness of the collaboration will be analysed through student's post, survey and observation.

This study uses an application called Padlet, a free web-based application available online. It can be accessed easily via computer or any mobile gadget with internet connection. This research observes student's response towards the use of Padlet in an English Language course at the undergraduate level.

\section{Literature Review}

\subsection{Collaborative Writing}

Collaboration is identified as one of the key elements in effective communication that is essential in developing 21st century skills. According to Greenstein (2012), effective collaboration is learning to plan and work together, to consider diverse perspectives and to participate in discourse by contributing, listening and supporting others. She further summarizes, that the ability to use 21st century skills is associated with the ability to process knowledge and information through spoken language, written communication and actions. Collaborative writing assignments have shown to enhance students interaction in the EFL classroom, lower anxiety associated with completing tasks alone and raise student's self-confidence (Mulligan \& Garofalo, 2011). Furthermore, cognitive and social interactions during collaborative learning can encourage higher level thinking for creation of new knowledge among undergraduates (Dewitt, Alias, Siraj, \& Zakaria, 2014). 
With the introduction of ICT in education, web 2.0 and mobile learning in today's education scenario, collaboration in teaching and learning have become easier, more productive, and interesting. Numerous platforms are used to get students to collaborate not only in class but also in the virtual world. Blogs, Facebook, Wikis and Padlet are some of the platforms favoured among teachers, as they brought about new opportunities and affordances for learning (Bishop \& Elen, 2014). For this study, Padlet, a web 2.0 tool, was used to facilitate collaborative writing in a university course.

Haring-Smith (1994: p. 360) defines collaborative writing as involving more than one person who contributes to the creation of a text so that "sharing responsibility" becomes essential. Collaborative writing occurs when two or more people working together to produce a document with group responsibility for the end product (Elola, 2010). Writing collaboratively is a natural phenomenon in the academic spheres. The sharing of knowledge and expertise among writers breeds a comprehensive piece of written product. This reflects sociocultural theory where knowledge is greatly enhanced in a social context (Vygotsky, 1978). In this course, students will have the opportunity to discuss and collaborate with each other throughout each step of their essay writing process. This could be helpful to students with lower proficiency because they have support in the form of their groupmates. With the addition of cloud based technology, learners now have the element of on-line, synchronous platform that could be accessed anywhere at all via mobile gadgets. This makes collaborative writing much easier and faster.

On the other hand, studies by Kwan and Yunus (2015) have discovered a less favourable acceptance towards collaborative writing using a web-based tool called Wiki. The study which focused on gifted students saw that they preferred working on their own and are not in favour of too many people working on one essay. This could indicate that students who are more proficient can work well on their own and regard collaboration as a hindrance, regardless of the platform it was conducted on.

This study focused on an English language course for lower proficiency students. The course objectives include writing an essay (collaborative effort) and making a short presentation of the same topic (individual). Students were taught the process of writing an informative essay. It begins with topic selection where students were allowed to choose any topic as long as they can write it from an academic standpoint. Once the class instructor approved their topics, they proceeded with their fact-finding research and construct an outline. They would then write an essay using the points and information they have gathered. Throughout this process, they consult their instructor frequently to make sure they are on track.

Ron White and Valeri Arndt (1991) outlined the connection between the processes in a dynamic web of interconnectivity. It requires many steps of going back and forth between generating ideas, structuring, drafting, focusing, evaluating and re-viewing. Coupled with the element of collaboration, this can be 
challenging process. Process writing like this involves constant cycle of thinking, drafting and rewriting. In this study students have to read academic texts, find key points, write their own part of the essay and together with their team, merge the points into one essay and ensure that it is a cohesive piece of writing. Editing and feedback was done within the group before they seek instructor's approval. This process involved many stages of peer reading and consultation between the group members and the instructor.

\subsection{Padlet as a Learning Tool}

Padlet (https://www.padlet.com) is a free web based application that provides a "wall" that allows the user to post words, pictures and even videos, which could be viewed by anyone with the link or address to the specific wall. Many researchers have shown how collaborative practices are encouraged exponentially with the advent of Web 2.0. Webtools such as Facebook and blogs have shown to have positive effect on student's language learning (Omar, Embi, \& Yunus, 2012). Effective representation in the mind generated through various modes of ICT help learners internalize knowledge and learn better (Dewitt, Alias, \& Siraj, 2015). It could be used as a whiteboard, with a lasting record, provide a backchannel for questions and feedback, to review, summarise and apply key points, and for after class activities if there are no time in class (Fisher, 2017). The application has also been used as an avenue for art appreciation online discussion board, reflection, and enabled students to collaborate safely with an online community (Delacruz et al., 2014). Padlet provides the ability to view a variety of responses that could allow opportunities for peer learning and self-assessment because students have immediate access to a wide spectrum of responses from classmates. Similar research of Padlet with a workplace communication course has also highlighted that Padlet improves teacher student relationship, increase motivation and self-esteem and provide teachers with an alternative mode of communicating with students beyond the classroom (Rashid, 2015). It can encourage real-time, whole class participation and assessment (Fuchs, 2014). In the context of this study, students post answers to questions from the instructor and all answers will be visible on the wall. Responses and feedback from instructor are also visible. Therefore, students are able to look at errors and suggestions and apply it when writing their answers. Comments and corrections from instructor and classmates can help students to reflect and allow for self-correction (Nizam et al., 2016). Padlet tasks in a professional work place communication course have helped students to develop their confidence and prepare for job interviews.

\section{Research Methods}

\subsection{Participants}

A total of 87 students took part in this study. The students were from a mixed discipline including Islamic Studies, Science and Technology and Economics 
and Management. The students enrolled in this course would have obtained MUET (Malaysian University Entrance Test) level 3 which describe them as a modest user. This implies that the level of ability is average with inaccuracies in vocabulary and sentence structures and limited variety in expressions (Malaysian Examination council).

\subsection{Research Instruments}

The research uses a combination of qualitative survey questions supported by document analysis. Seven Padlet tasks spread across the 14 weeks of the semester to supplement weekly class sessions. The tasks were assigned in class and also through the university's own e-learning platform. Students were given the link to individual class walls where they can post their answers or comments.

\subsubsection{Questionnaire}

A set of questionnaire were used to gather feedback on student's response to the task throughout the semester and to see if they have found Padlet to be a motivating platform to learn from and if they have benefited from it. The forms were constructed with Google Forms and distributed online. A statistical analysis was derived from the Google Form apps and the analysis indicated whether Padlet has served its purpose in the course and has helped increase student's motivation in learning as well as helped students accomplish their projects well.

\subsubsection{Task Analysis}

A series of Padlet tasks were designed for the students to carry out after class and they are related to activities that were done in class each week. The reason for this is that it is meant to complement the activities or discussions in class. It is also a tool to ensure that group work outside of class were carried out and submitted within the time limit given. Students posts on the Padlet wall were analysed for language use, proficiency and comprehension.

\subsubsection{Teacher Observation}

Teacher's observations were used to gauge student's motivation towards the tasks, collaborative efforts, as well as language use and development. The researcher took on the role of a participant observer in this study, and collected data from class sessions, online interaction among students as well as one-to one interaction with students.

\section{Findings}

The results of the questionnaires were tabulated by Google form apps and showed that the biggest motivating factor is the fun and colourful design of the application. This is followed by the ability to read everyone's posts, user friendly, and able to access from most mobile gadget and anywhere via internet.

\subsection{Motivation}

Table 1 lists the questions concerning motivation aspect from the questionnaire 
distributed to the students after the course ended. Over 90\% found that Padlet motivates them to complete tasks and interact with their group members outside of the class. Most importantly $97.5 \%$ agreed that Padlet encourage interaction and collaboration when completing tasks.

The features of Padlet application has been a significant contributing factor to student's motivation and active participation in class activities and communication. Figure 1 shows some of students' questions and responses to the instructor's feedback. Students would post regularly, and also respond to feedback. Students would post not only questions or comments, but also pictures, videos and links for other classmates to read. This also made the class wall an avenue for knowledge sharing. On the part of the instructor, teaching objectives are more achievable due to the application's features that are intuitive, accessible and helps reduce learner anxiety in the classroom environment and motivate them to continue out of class.

Table 2 shows $97.5 \%$ of the participants prefer working in groups and a unanimous response agreed that they feel less stressed when working in a group.

\subsection{Collaboration}

95\% are in favour of Padlet as a medium that encourages interaction among group members outside of classroom (Table 3, question 4). 97.5\% agreed that Padlet encourages collaboration (question 5).

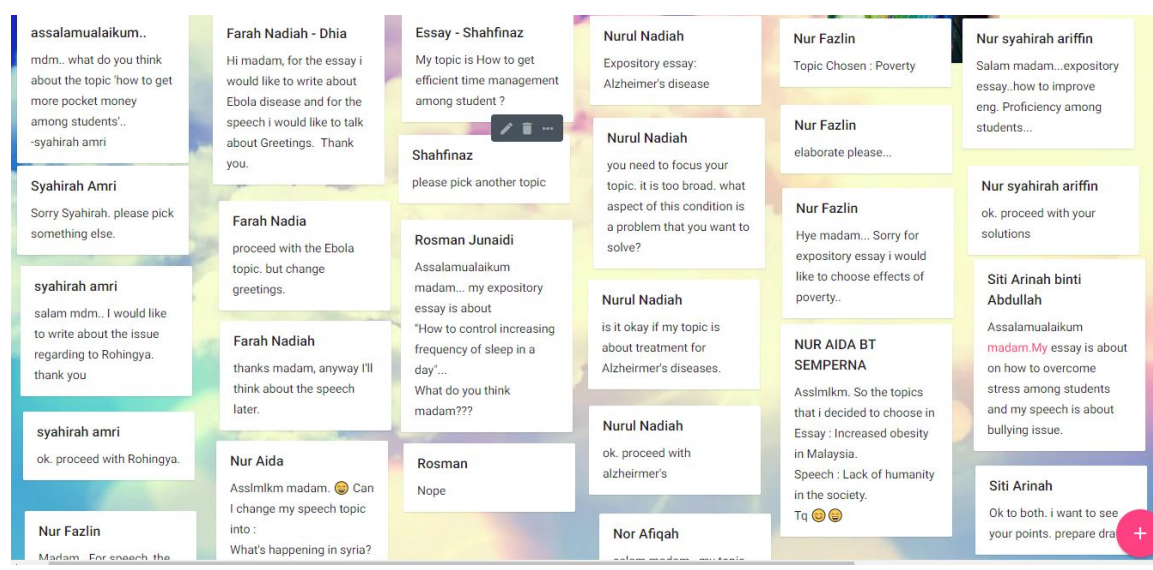

Figure 1. Screen capture of topic choices and feedback from instructor (https://padlet.com/aidarashid/set57acadcom1).

Table 1. Analysis of student's responses: Motivation.

\begin{tabular}{lcccc}
\hline \multicolumn{1}{c}{ Questions } & $\begin{array}{c}\text { Strongly } \\
\text { Agree } \%\end{array}$ & $\begin{array}{c}\text { Agree } \\
\%\end{array}$ & $\begin{array}{c}\text { Disagree } \\
\%\end{array}$ & $\begin{array}{c}\text { Strongly } \\
\text { Disagree \% }\end{array}$ \\
\hline $\begin{array}{l}\text { 4. Padlet motivates me to complete tasks } \\
\text { assigned by my instructor. }\end{array}$ & 30 & 67.5 & 2.5 & - \\
$\begin{array}{l}\text { 5. Padlet motivates me to interact with } \\
\text { my group members outside of class. }\end{array}$ & 37.5 & 57.5 & 5 & - \\
$\begin{array}{l}\text { 6. Padlet encourages my group to } \\
\text { interact and complete tasks together. }\end{array}$ & 40 & 57.5 & 2.5 & - \\
\hline
\end{tabular}


Table 2. Analysis of student's responses: Lower learning anxiety.

\begin{tabular}{lcccc}
\hline \multicolumn{1}{c}{ Questions } & $\begin{array}{c}\text { Strongly } \\
\text { Agree } \%\end{array}$ & $\begin{array}{c}\text { Agree } \\
\%\end{array}$ & $\begin{array}{c}\text { Disagree } \\
\%\end{array}$ & $\begin{array}{c}\text { Strongly } \\
\text { Disagree \% }\end{array}$ \\
\hline $\begin{array}{l}\text { 9. I prefer working in a group to complete } \\
\text { my essay project than working alone. }\end{array}$ & 45 & 52.5 & 2.5 & - \\
$\begin{array}{l}\text { 10. I feel less stressed when I work in } \\
\text { a group to complete the essay project. }\end{array}$ & 60 & 40 & - & - \\
\hline
\end{tabular}

Table 3. Analysis of student's responses: Collaboration.

\begin{tabular}{lcccc}
\hline \multicolumn{1}{c}{ Questions } & $\begin{array}{c}\text { Strongly } \\
\text { Agree } \%\end{array}$ & $\begin{array}{c}\text { Agree } \\
\%\end{array}$ & $\begin{array}{c}\text { Disagree } \\
\%\end{array}$ & $\begin{array}{c}\text { Strongly } \\
\text { Disagree } \%\end{array}$ \\
\hline $\begin{array}{l}\text { 4. Padlet motivates me to interact with } \\
\text { my group members outside of class. }\end{array}$ & 37.5 & 57.5 & 5 & - \\
$\begin{array}{l}\text { 5. Padlet encourages my group to interact } \\
\text { and complete tasks together. }\end{array}$ & 40 & 57.5 & 2.5 & - \\
\hline
\end{tabular}

\subsection{Language Use}

The techniques of learning language become more varied when Padlet is incorporated into the class activities. Table 4 shows $97.5 \%$ of the students agree that they learn from each other by reading comments from their classmates. Because of the nature of their post being made public on the class wall, $97.5 \%$ of the participants are careful to edit and check for language accuracy before posting. Almost all participants agree that Padlet has helped in completing their Essay.

Figure 2 below shows how students tend to emulate their friend's sentence structure when writing their posts. This is helpful especially among lower proficiency students as they have a model of the language in use to learn from. Posting on the class wall means making it public for the rest of the class to read. Padlet encourages students to self-edit before posting. This encourages students to be independent in their language learning. Although they do make some grammar error in the posts, the instructor views this as a learning opportunity and provides language feedback, during face-to-face consultations. Their language errors will not be highlighted on the wall for fear of demotivating them. Students agree that they do learn from their classmates by reading their posts and comments on the class wall. Learning from an online collaboration tool like Padlet reinforces the shift in roles of students and instructors. Students are now placed in the roles of active participants in the learning process and are no longer passive recipients of information (Anderson, 2010).

\subsection{Observation}

Throughout the semester, the researcher has observed that, students like to post their responses on Padlet. They enjoyed getting feedback from the instructor as well as their peers. This was observed from the students' regular posts and 


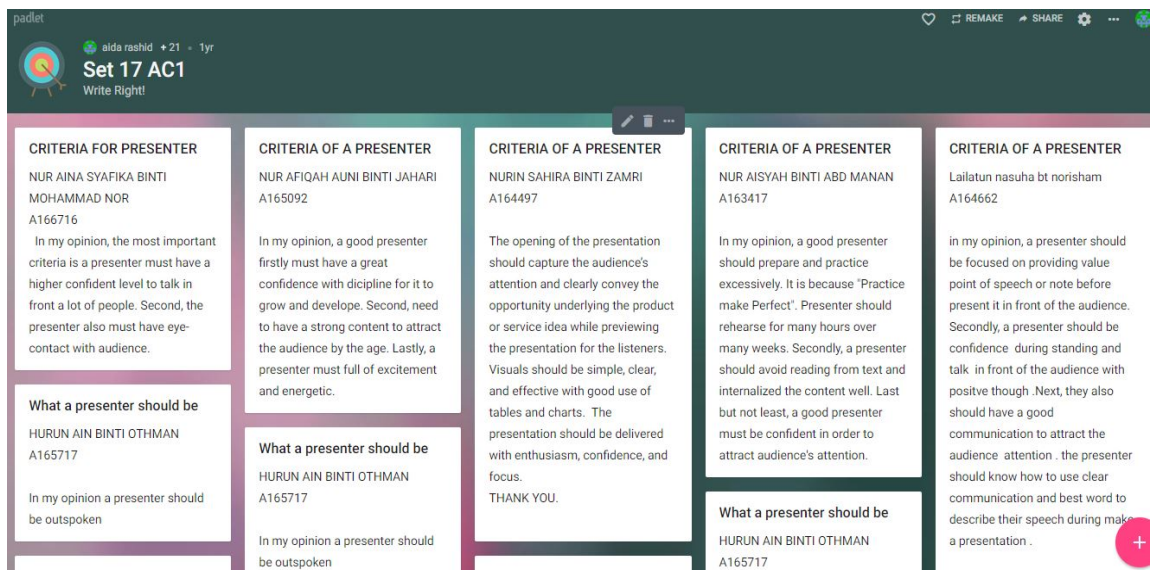

Figure 2. Screen capture of students post: emulating the post before to structure their comments (https://padlet.com/aidarashid/set17AC1).

Table 4. Analysis of student's responses: Language.

\begin{tabular}{lcccc}
\hline \multicolumn{1}{c}{ Questions } & $\begin{array}{c}\text { Strongly } \\
\text { Agree } \\
\%\end{array}$ & $\begin{array}{c}\text { Agree } \\
\%\end{array}$ & $\begin{array}{c}\text { Disagree } \\
\%\end{array}$ & $\begin{array}{c}\text { Strongly } \\
\text { Disagree } \\
\%\end{array}$ \\
\hline $\begin{array}{l}\text { 6. Padlet allows me to learn from my classmates by } \\
\text { reading their posts and comments on our class wall. }\end{array}$ & 42.5 & 55 & 2.5 & - \\
$\begin{array}{l}\text { 7. When I post on Padlet wall, I am careful to } \\
\text { check my grammar and use the right words. }\end{array}$ & 47.5 & 50 & 2.5 & - \\
$\begin{array}{l}\text { 8. Using Padlet helps me prepare for } \\
\text { my essay project. }\end{array}$ & 27.5 & 67.5 & 5 & - \\
\hline
\end{tabular}

participation from every students in the class. Interviews with students showed that some had reservations about posting their comments on-line because of their weak language proficiency. They were self-conscious of the fact that all their classmates could read their posts. However, since their language level was very similar, they gradually became more open towards posting on the class wall. This encouraged them to edit their writing before posting on-line. Practice in accuracy occurs often before posting their comments where they would check for grammar error and vocabulary accuracy as best as they can.

\section{Discussion}

All Padlet tasks are assigned through the university's online portal, or announced in class. The teacher will then review their posts in class or respond to them online. The ease to communicate with each other on Padlet among the participant of this study proves that Padlet is a good alternative to reduce communication gap among student, teachers and peers (Dewitt, Alias, \& Siraj, 2015).

The tasks centred on Padlet encouraged students to coordinate with their group members and facilitate their project throughout the semester. The ability to work in teams and coordinate with others has been highlighted as one of the demands of the $4^{\text {th }}$ Industrial Revolution, and an essential $21^{\text {st }}$ century skill 
(MdZamin, Abdul Majid, \& Kamaruddin, 2017). Thus, this would help hone the skills earlier in the course of their studies.

Language learning occurred when students were able to learn from their peers' posts and feedback, as well as the instructor's feedback. The class "wall" becomes a source of reference. Participating in the Padlet tasks out of class time extends student's learning time beyond the classroom and encourages autonomous learning. Using the target language out of classroom also gives them a sense of achievement. This was similarly reported in a study by Saad, Yunus and Embi (2014), which showed the students associated practicing and using English as a form of success. Thus the use of this application can provide the motivation that the students need as well as positive reinforcement. This study also revealed an almost unanimous preference of working in groups to complete their essay rather than working alone. The collaborative aspects has successfully eliminated the stress and anxiety associated with writing tasks.

\section{Recommendations and Limitations}

It is important for educators to be clear on the types of applications that could best assist them in teaching and making the most of their class. Features such as user friendly, attractive layout and communicative are some of the elements that teachers need to consider before adopting it to class use.

One of Padlet's key features is that it allows feedback from instructor and peers and shared information to become a permanent record for the students to refer to throughout the semester. This can serve as a reference and resource for the teacher too. For this researcher, the key factor in online teaching tools comes down to simplicity and accessibility. Simplicity is attributed to the main purpose of the application and user friendly, intuitive features. This allows room for creativity and personalisation. Not only does this motivate students, it also motivates the teachers. Since Padlet is an online tool which is also mobile friendly, it can be accessed virtually anywhere and anytime, making the classroom experience truly borderless and at the same time appealing to the new generation of learners.

This study was carried out in a local university among the population of first year students with average to lower level of proficiency in the English Language. It is their first English language course, which focuses on basic academic reading and writing skills. Thus, the findings are limited to this population and context. Further studies among different levels of students or courses could yield more information and techniques on how this application could be used to its fullest to benefit student's learning experience in a holistic way.

\section{Conclusion}

The implication of this study is that on-line learning tools such as Padlet have the potential to create an environment that can encourage collaboration among learners and help improve language accuracy through a peer assisted learning 
like method. This will enable teachers to take on the role of facilitators and lead students to become autonomous learners. For lower proficiency students, the ability to do so would lead to the increase in confidence and a more positive perception towards language learning.

\section{Conflicts of Interest}

The authors declare no conflicts of interest regarding the publication of this paper.

\section{References}

Anderson, J. (2010). ICT Transforming Education: A Regional Guide. Bangkok: UNESCO.

Bishop, M. J., \& Elen, J. (2014). Emerging Technologies. In J. M. Spector, M. D. Merrill, J. Elen, \& M. J. Bishop (Eds.), Handbook of Research on Educational Communications and Technology (pp. 413-424). New York: Springer.

Delacruz, E., Brock, D., Fuglestad, T., Ferrell, K., Huffer, J., \& Melvin, S. (2014). Teaching Art in the Age of Social Media: Firsthand Accounts of Five Technology-Savvy Art Teachers. http://www.elizabethdelacruz.com/uploads/5/4/3/6/5436943/delacruz_5techteachers.pd $\underline{\mathrm{f}}$

DeWitt, D., Alias, N., \& Siraj, S. (2015). Collaborative Learning: Interactive Debates Using Padlet in a Higher Education Institution. In International Educational Technology Conference (IETC 2015), 27-29 May 2015, Istanbul, Turkey. (Submitted)

DeWitt, D., Alias, N., Siraj, S., \& Zakaria, A. R. (2014). Interactions in Online Forums: A Case Study among First Year Undergraduate Students. Frontiers in Education, 2, 6-13.

Elola, I. (2010). Collaborative Writing: Fostering Foreign Language and Writing Conventions Development. Language Learning \& Technology, 14, 51-71.

Fisher, C. D. (2017). Padlet: An Online Tool for Learner Engagement and Collaboration. Academy of Management Learning \& Education, 16, 163-165. https://Padlet.com https://doi.org/10.5465/amle.2017.0055

Fuchs, B. (2014). The Writing Is on the Wall: Using Padlet for Whole-Class Engagement. LOEX Quarterly, 40, 7.

Greenstein, L. M. (2012). Assessing 21st Century Skills: A Guide to Evaluating Mastery and Authentic Learning. Corwin Press.

Haring-Smith, T. (1994). Writing Together: Collaborative Learning in the Writing Classroom. HarperCollins College Publishers.

Kwan, L. S., \& Yunus, M. M. (2015). Group Participation and Interaction in ESL Wiki Collaborative Writing among Malaysian Gifted Students. Asian Social Science, 11, 59.

Lin, O. P., \& Maarof, N. (2013). Collaborative Writing in Summary Writing: Student Perceptions and Problems. Procedia-Social and Behavioral Sciences, 90, 599-606. https://doi.org/10.1016/j.sbspro.2013.07.131

MdZamin, A. A., Abdul Majid, F., \& Kamaruddin, M. F. (2017). Toolkits for 21st Century Teaching: Practical Implications for the 4th Industry Skills Development. Shah Alam: Penerbit UITM.

Mulligan, C., \& Garofalo, R. (2011). A Collaborative Writing Approach: Methodology and Student Assessment. The Language Teacher, 35, 5-10. 
Nizam, A. S. et al. (2016). Empowering Student's Competencies through Padlet.

Omar, H., Embi, M. A., \& Yunus, M. M. (2012). ESL Learners' Interaction in an Online Discussion via Facebook. Asian Social Science, 8, 67. https://doi.org/10.5539/ass.v8n11p67

Rashid, A. (2015). Enhancing Class Activities Using Padlet: A Teacher's Reflection.

Saad, N., Yunus, M. M., \& Embi, M. A. (2014). The Successes and Challenges in English Language Learning Experiences of Postgraduate International Students in Malaysia. Mediterranean Journal of Social Sciences, 5, 206. https://doi.org/10.5901/mjss.2014.v5n19p206 http://www.mcser.org/journal/index.php/mjss/article/view/4246

Shehadeh, A. (2011). Effects and Student Perceptions of Collaborative Writing in L2. Journal of Second Language Writing, 20, 286-305. https://doi.org/10.1016/j.jslw.2011.05.010

Storch, N. (2005). Collaborative Writing: Product, Process, and Students' Reflections. Journal of Second Language Writing, 14, 153-173. https://doi.org/10.1016/j.jslw.2005.05.002

Swain, M. (2000). The Output Hypothesis and Beyond. In J. Lantolf (Ed.), Sociocultural Theory and Second Language Acquisition (pp. 97-114). Oxford: Oxford University Press.

Vygotsky, L. S. (1978). Mind in Society. Cambridge, MA: Harvard University Press.

Wells, G. (2000). Dialogic Inquiry in Education. Building on the Legacy of Vygotsky. In C. Lee, \& P. Smagorinsky (Eds.), Vygostkian Perspectives on Literacy Research. Constructing Meaning through Collaborative Inquiry (pp. 51-85). Cambridge: Cambridge University Press.

Wenger, E. (1998). Communities of Practice: Learning, Meaning, and Identity. New York: Cambridge University Press.

White, R., \& Arndt, V. (1991). Process Writing. Longman: Essex. 